\title{
Peningkatan Pengetahuan Mengenai Manfaat Pelabelan pada Kemasan Produksi Nugget Telor Asin
}

\author{
Improvement of Knowledge About The Benefits of Labeling in Salted Egg Nugget \\ Production Packges
}

\author{
Dumadi $^{* 1}$, Teguh Arifianto ${ }^{2}$, Masrini Dian Utami ${ }^{3}$, Indah Dewi Mulyani ${ }^{4}$ \\ $1^{*}, 3,4$ Prodi Manajemen, Fakultas Ekonomi Dan Bisnis, Universitas Muhadi Setiabudi Brebes, Indonesia \\ ${ }^{2}$ Prodi Teknologi ElektroPerkretaapian, Politeknik Perkretaapian Indonesia

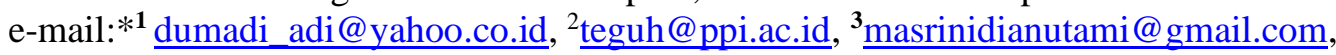

\begin{abstract}
ABSTRAK
Kegiatan peningkatan pengetahuan mengenai manfaat pelabelan pada kemasan produksi nugget telor asin tujuannya adalah memberikan pengetahuan tambahan terkait desain label dan kemasan makanan. Kegiatan pelaksanaan ini dilakukan kepada ibu-ibu kader warga Losari Lor, Kecamatan Losari, Kabupaten Brebes yang berjumlah 20 orang di Balai Desa Losari Lor. Penyuluhan ini dilaksanakan oleh mahasiswa dan dosen fakultas ekonomi dan bisnis Universitas Muhadi Setiabudi. Hasil penyuluhan ini ialah kepada ibu-ibu kader mempunyai pengetahuan tambahan dalam membuat label makanan dan kemasan yang lebih menarik untuk memberikan nilai tambah ekonomis dari produk olahannya.
\end{abstract}

Kata Kunci : Label, Kemasan.

\begin{abstract}
The activity of increasing knowledge about the benefits of labeling on salted egg nugget production packaging aims to provide additional knowledge related to label design and food packaging. This implementation activity was carried out for 20 cadres of Losari Lor residents, Losari District, Brebes Regency at the Losari Lor Village Hall. This counseling was carried out by students and lecturers of the Faculty of Economics and Business, Muhadi Setiabudi University. The result of this counseling is that cadre mothers have additional knowledge in making food labels and packaging more attractive to provide added economic value from their processed products.
\end{abstract}

.Keywords : Label, Packaging.

\section{PENDAHULUAN}

Label merupakan bagian dari produk itu sendiri berupa penjelasan bentuk gambar, atau kata/ tulisan yang mempunyai fungsi informatif tentang produk dan sipenjual. Label pada dasarnya berisikan penjelasan berupa merekproduk, bahanbaku, isiproduk, kandungan gizi, masa kedaluwarsa, berat neto dan legalitasnya produknya.

Pelabelan pada kemasan produk sangat penting bagi pelaku bisnis yang bergerak dibidang industri makanan. Karena hal ini dapat dijadikan untuk media promosi bagi pelaku usaha untuk memasarkan dan mengembangkan produksinya. Industri makanan ringan dari tahun ketahun semakin berkembang di Indonesia. Hal tersebut menjadikan banyak pelaku bisnis mencoba untuk melakukan bisnis dengan memproduksi makan ringan baik dalam penjualan ataupun memproduksi produk makanan ringan itu sendiri. Tetapi sebagian pelaku bisnis banyak yang tidak memahami pentingnya pelabelan pada kemasan produknya.

Banyak produsen yang berlomba-lomba menciptakan produk dengan kemasan semenarik mungkin untuk memasarkan produknya. Dalam hal ini tidak akan lepas akan pentingnya pelabelan pada kemasan yang semenarik mungkin sehingga banyak konsumen yang merasa tertarik untuk membeli produknya. Pelaku bisnis atau pengusaha yang tanggap pasti akan

Submitted: Juli 2021, Accepted: Agustus 2021, Published: Agustus 2021

ISSN 2746-6345 (media online) 
memikirkan tentang pentingnya kemasan dan pelabelan tersebut biarpun akan memberikan biaya tambahan pada proses produksinya.

Label pada kemasan akan dijadikan ciri atau identitas bagi pelaku bisnis ataupun pengusaha yang membuat perbedaan dari produk yang diproduksi oleh masing-masing pelaku bisnis. Tentunya akan ada persaingan dalam pembuatan label kemasan untuk menarik konsumen supaya membeli produknya. Akan tetapi hal ini pasti akan diperhitungkan oleh pelaku bisnis karena akan menambah lagi untuk biasa produksinya.

Pengertian label dari marinus (2002), label ialah salah satu bagian dari sebuahproduk yang memberikan informasi/penjelasan verbal terkait produk dan pembuatnya. Pendapatt kotler (2000). Label ialah penampilan sederhana bagian produk atau gambardesain yang dibuat lebih rumit dan merupakan menyatu bersama kemasannya. Tujuan pemberian Label produk seperti dibawah ini.

a. Memberi penjelasan terkait isi produk tanpa harus membukanya kemasannya.

b. Memberikan fungsi sebagai alat/sarana komunikasi produsen/pembuat kepada konsumen atau calon konsumen terkait apa yang perlu diketahuinya oleh konsumen, baik informasi barang tersebut, terutama hal yang kelihatan mata secara langsung atau tidk bisa secara langsung fisiknya.

c. Sebagai petunjuk konsumen yang pas, hingga calonkonsumen memperoleh informasi guna produk secara maksimal.

d. Sarana iklan bagi siprodusen/pembuat produk.

e. Memberikan kenyamanan bagi calonkonsumen.

Label terbuat dari kertas atau film plastik yang diberi perekat atau tidak ada perekat Label bisa mencakup semua kemasan atau sebagaian dari kemasan saja. Bentuk kemasan lebih fleksibel seperti film dapat disusutregangkan yang biasa dipakai sebagai label.

Bahan label bila ditempelkan pada kemasan dengan cara memanasi, meregangkan mengikuti bentuk kemasan yang dilapisinya. plastik, botolkaca, kaleng dan bagian kaku lainnya bisa dilapisi dengan kemasan ini. Bentuk label bisa bermacamvariasi mulai dari identitasproduk yang sederhana sampai bentuk rumit yang merupakan kesatuan dari kemasan itu sendiri.

Label memberikan bermacam-macam fungsi sampai pada tingkatan paling terakhir, label memberikan identifikasi produk atau merk. Label juga memberikan penjelasan beberapa hal terkait barang, siapa produsennya, tempat produksinya, bahannya, isinya, dan bagaimana cara produk tersebut digunakan atau dikonsumsi.

Pendapat Kotler(2000: 478), label berfungsi sebagai berikut.

a. Label memberikan identifikasi suatu barang atau merek.

b. Label memberikan kelas atau predikat suatu barang.

c. Label memberi gambaran mengenai barang itu sendiri.

d. Label bagian promosi produk itu sendiri melalui berbagai gambar yang menarik.

Karena pelabelan pada kemasan merupakan strategi menarik untuk promosi yang didalamnya bisa berisikan jenis produk, nama merek, bahan yang digunakan, ataupun kontak pelaku bisnis yang bisa dihubungi oleh konsumen untuk memesan produknya. Contohnya pada proses pembuatan nugget telor asin yang dibuat oleh ibu-ibu kader warga Losari Lor Kecamatan,Losari Kabupaten Brebes, memperkenalkan produk nugget telor asin tersebut menggunakan kemasan yang menggunakan label pada kemasannya yang awalnya hanya kemasan menggunakan kemasan mika biasa tanpa label.

Pada pembuatan label pada kemasan dibuat semenarik mungkin sehingga konsumen merasa tertarik. Contohnya dalam hal pemilihan warna ataupun penulisan merk serta kata-kata yang membuat konsumen merasa penasaran untuk membeli produk tersebut. Pada pembuatan nugget telor asin ini menggunakan label kemasan yang warnanya terang dan penggunaan katakata yang menarik. Selain karena memperkenalkan produk nugget dengan inovasi baru yaitu telor asin yang merupakan makanan khas dari daerah sendiri yaitu kota Brebes, jadi sangatlah penting label pada kemasan karena konsumen akan tahu nugget tersebut menggunakan bahan utama telor asin pada produksinya. 
Pendapat Kotler (2003) pengemasan/paking ialah kegiatan membuat dan merancang sebuah wbungkus atau tempat barang, sedangkan pendapat SwastaBasu (1999) menerangkan kemasan ialah kegiatan yang umum serta perencanaan produk yang mengikutkan penentuan desainkemasan suatu produk. Jadi boleh dikatan bahwa kemasan ialah suatu kegiatan membuat rancangan dan membuat bungkus barang yang meliputi bentukdesain dan membuat bungkus barang tersebut.

Oleh karenanya kemasan merupakan bagian daristrategi pemasaran, khususnya strategik kemasan produk yang bisa dibuat dengan cara perbaikan bentuk luarnya seperti logo, warna, bentuk huruf, pembungkus, etiket, dan lain sebagainya agar lebih memikat perhatian calonkonsumen dan bisa memberikan kesan, bahwa barang tersebut berkualitas baik.

Pendapat Cenadi (2000) menjelaskan kemasan dapat diartikan sebagai kegiatan membuat rancangan dan membuat tempatwadah atau bungkus suatu barang. Kemasan meliputi beberapa hal sebagai berikut.

1. Kemasan harus memenuhi persyaratan aman, melindungi dan bermanfaat.

2. Kemasan bagian dari pemasaran. Dengan kemasan dapat terlihat identifikasi produk menjadi lebih efektif dan mencegah salah tukar dengan produk lain.

3. Kemasan bisa meningkatkan omset perusahaan,maka produsen harus membuat bentuk kemasan lebih menarik.

Dengan bentuk kemasan yang lebih menarik maka dapat memikat perhatian calonkonsumen agar membeli sebuah barang. Selain itu juga kemasan dapat mengurangi terjadinya kerusakan barang dan mempermudah dalam distribusi.

Natadjaja,(2002) menjelaskan bahwa fungsi paking lebih dari berfungsi teknis. Paking justru mempunyai fungsi sebagai "Ambasador",atau“Duta Besar" yang berfungsi mewakili semua konsep produk itu sendiri. Kemasan produk biasanya berlapis tidak hanya satu lapis saja karena kemasan bisa dengan tujuan yang berbeda. Macam-macam kemasan terdiri dari :

1. Kemasan dasar atau Primer Package yaitu bungkus langsung produk itu sendiri.

2. Kemasan tambahan atau Secondary Package, yaitu bahan yang dapat melindungi kemasan dasar, yang biasanya dibuat semenarik mungkin dengan desain yang beragam.

3. Kemasan pengiriman/Shipping package, yakni kemasan yang digunakan untuk penyimpanan dan pengiriman produk.

Fungsi kemaan yang diharapkan adalah sebagai berikut :

1. Melindungi produk terhadap kerusakan saat barang diproduksi sampai barang dikonsumsi.

2. Mempermudah pengerjaan dan menyimpan barang dilakukan oleh siprodusen, perantara ataupun konsumen.

3. Menarik calonkonsumen agar mereka belanja di minirmarket atau sebagai bagian promosi.

Label menyatu dengan paking,. Pendapatt Kotler (2003) label ialah tempelan sederhana pada sebuah barang atau gambar dengan rancangan rumit dan sebagai satu kesatuan dengan paking. Label merupakan sebagian dari paking secara keseluruhan dan harus perlu dipertimbangkan pada tahapan awal proses desain kemasan. Label boleh mencantumkan merek, atau dapat juga mencantumkan banyak informasi. Label pada hakekatnya mempunyai bermacam-macam fungsi seperti mengidentifikasi merk produk, menentukan kelas produk dan informasi produk, bentuk promosi produk dengan gambar menarik.

Pelabelan pada kemasan ini diharapkan akan meningkatkan daya minat beli konsumen kepada produk nugget telor asin, sehingga akan mendatangkan keutungan lebih bagi para ibuibu kader untuk memulai bisnis. Hal ini bisa dijadikan oleh pelaku usaha lain yang bukan hanya bergerak dibidang makanan ringan saja, supaya mengetahui pentingnya pelabelan pada kemasan produksinya.

Berdasarkan gambaran permasalahan diatas dapat disimpulkan bahwa pelabelan pada kemasan dapat meningkatkan daya beli konsumen, hal inilah yang melatar belakangi untuk mengadakan penyuluhan tentang pentingnya pelabelan pada kemasan produksi nugget telor asin kepada ibu-ibu kader warga Losari Lor, Kecamatan Losari, Kabupaten Brebes. 


\section{METODE PELAKSANAAN}

Penyuluhan tentang pentingnya pelabelan pada kemasan ini dilaksanakan pada ibu-ibu kader warga Losari Lor Kecamatan, Losari Kabupaten Brebes yang diikuti sebanyak 8 peserta (secara sukarela) yang terlibat dalam pelaku usaha dibidang makanan ringan.

Penyuluhan ini dilaksanakan pada 6 September 2020. Target sasaran untuk penyuluhan ini yaitu ibu-ibu kader yang memiliki usaha bisnis dalam bidang penjualan makanan dengan tujuan agar dapat menerapkan penggunaan label pada kemasan yang dulu hanya menggunakan kemasan biasa tanpa label. Serta untuk mengenalkan produk inovasi baru dari pengolahan nugget yang berbaha dasar telor asin yang nantinya dapat memberikan tambahan variasi dalam bisnis penjualan makanan ringan tersebut.

Tentunya dalam menarik konsumen agar lebih tertarik akan suatu produk yang dihasilkan perlu adanya label yang bisa memikat pembeli, hal ini akan menambah keuntungan hasil pelaku bisnis tersebut. Kottler dalam Marketing Management (2003) berpendapat minat beli ialah suatu tahapan yang dilakukan konsumen sebelum merencanakan membeli suatu produk. Tahapan tersebut bagian AIDAS yaitu: Attention, Interest, Desire, Action, Satisfaction.

Pelaksaan kegiatan penyuluhan ini menggunakan metode bicara langsung dan menggunakan bantuan alat seperti laptop untuk mendesain label pada kemasannya. Serta alat bantu lain seperti alat tulis dan alat masak untuk memproduksi nugget telor asinnya. Pendapatt Kotler (2003) ada 6 elemen yang wajib dipenuhi ketika membuat desain sebbuah produk yakni, bentuk, ukuran, bahan, warna, text dan merk. Pelaksanaan penyuluhan ini dibagi beberapa tahapan yaitu sebagai berikut.

1. Tahap Awal atau Persiapan

Tahap ini yaitu merancang dan mempersiapkan semua alat serta bahan yang digunakan dalam penyuluhan tersebut seperti media yang digunakan laptop sebagai alat utama dalam mendesain label kemasan. Alat dapur seperti kompor, wajan, pisau dan lain-lain. Seta mempersiapkan bahan untuk pengolahan nugget telor asin dan alat tulis. Serta mempersiapkan materi yang akan dibahas dalam penyuluhan ini yang dibantu oleh mahasiswa KKN Universitas Muhadi Setia Budi seperti materi untuk wawancara.

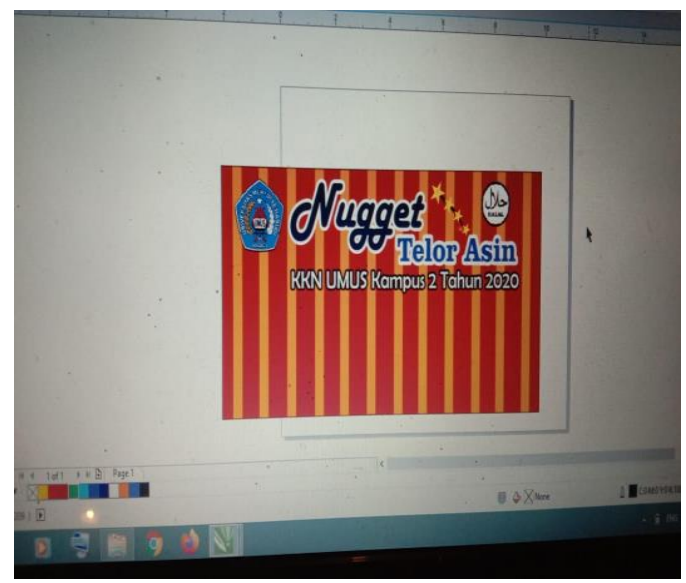

Gambar 1. Desain Label Nugget Telor Asin

2. Tahapan Pelaksanaan

Tahapan ini dilakukan di Balai Desa Losari Lor pada 6 September 2020. Metode pada tahapan pelaksanaan ini ialah penyuluhan dan pelatihan pembuatan nugget telor asin. Tahapan ini melihat sejauh mana peserta bisa mengimplementasikan apa yang sudah dijelaskan oleh pemateri , kemudian dilakukan evaluasi pada tanggal 10 September 2020. 


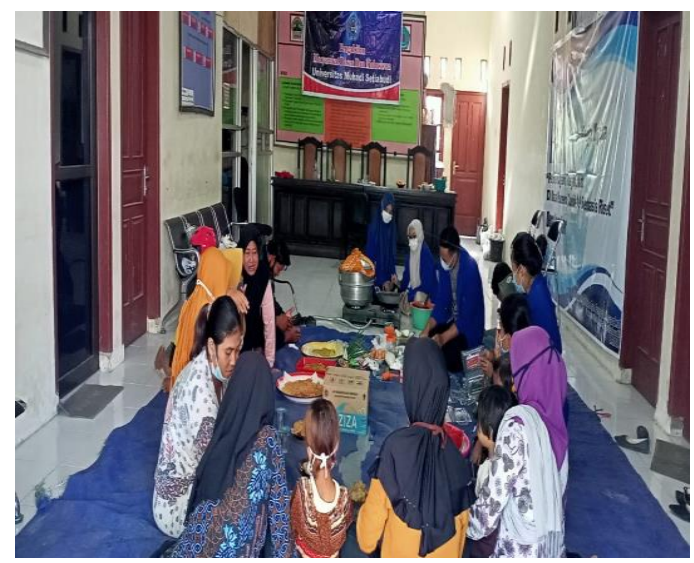

Gambar 2. Pelatihan Pembuatan Nugget Telor Asin

3. Tahap Evaluasi

Di tahapan ini evaluasi dilakukan pengumpulan data desain label serta hasil pelaksanaan dari pembuatan nugget telor asin yang di laksanakan oleh ibu-ibu kader Desa Losari Lor Kecamatan Losari Kabupaten Brebes.

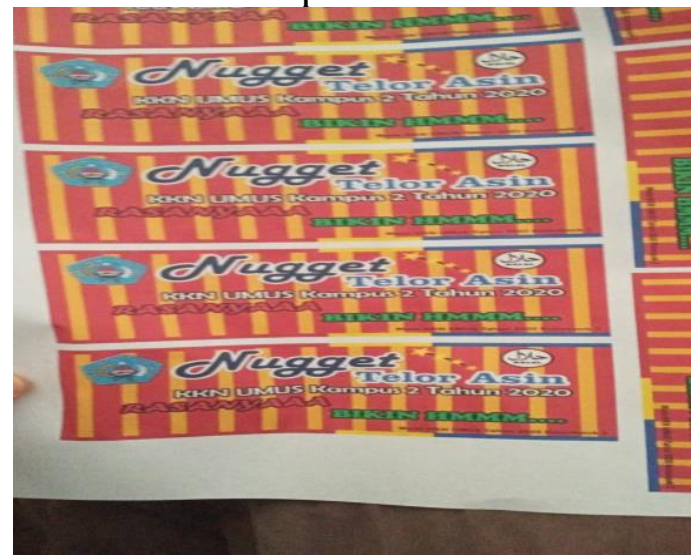

Gambar 3. Hasil Pelatihan Desain Label

Pendapat Bhakti(2001) dalam Natadjaja(2002) menerangkan paking seharusnya sebagai kesan singkat atas citra barang. yang ingin disampaikan oleh produsen dan paking haruslah lebih terpadu dengan fungsi produk. Desain paking membutuhkan banyak pemikiran dan bukan hal yang mudah.Yang lebih penting, paking juga menggambarkan merek suatu produk, bila orang melihat merek tersebut mereka tertarik ataskemasan produk tersebut, dan membeli produk tersebut.

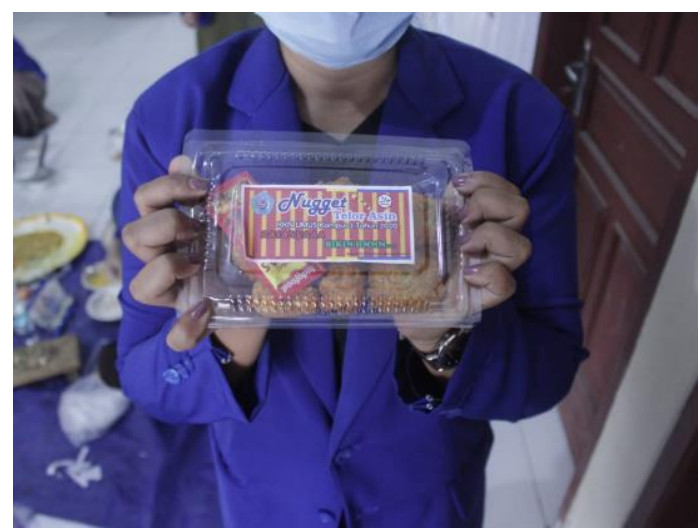

Gambar 4. Hasil Pelaksanaan Pembuatan Nugget Telor Asin 


\section{HASIL PEMBAHASAN}

Paking itu desain kreatif yang memadukan warna, bentuk, citra,struktur, bahan, tipografi. Elemen desain sebagai informasi barang agar barang bisa dipasarkan. Kemasan difungsikan untuk melindungi produk, keamanan, mengirim, mengeluarkan, menyimpan, identitas produk dan membedakan dengan produk lainnya..

Pengemasan ialah pekerjaan merancang, mendesain dan membuat wadah bungkus sebuah barang. Biasanya kegunaan utama dari paking ialah untuk menjaga barang. Kemasan juga menjadi faktor yang cukup penting yaitu sebagai bagian pemasaran Kemasan yang direncana dengan baik bisa membangun ekuitas merek dan bisa meningkatkan omset penjualan. Kemasan ialah hal pertama produk yang dilihat atau dihadapi konsumen dan bisa menarik atau menyingkirkan konsumen. Pengemasan/paking suatu produk biasanya dilakukan oleh produsen/pembuat produk untuk dapat merebut minat beli konsumen terhadap produk tersebut. Produsen berupaya memberikan kesan baik pada kemasan produk dan membuat model kemasan baru agar berbeda dengan produsen lain yang memproduksi produk sejenisnya. Beberapa yang harus diperhatikan saat membuat kemasan, yaitu sebagai berikut.

1. Efektivitas kemasan sesuai dengan kebutuhan yang dibutuhkan dalan mengemas produk.

2. Keamanan pangan atau food safety. Bentuk kemasan dan cara mempaking harus aman, tidak boleh mengandung zat yang berbahaya, dan harus bebas kuman sehingga barang aman tidak rusak,tidak bau, dan keamanan produk terjaga kualitasnya.

3. Mudah dalam pengiriman. Yang perlu dipertimbangkan besar kecil ukuran, dan kekuatan agar proses pendistribusian produk mudah dilakukan dan tanpa merusak produk.

4. Cepat dikenali. Kemasan dibuat semenarik mungkin dan dibedakan dengan barang lain agar cepat dikenali dan diingat konsumen.

5. Desain aergonomis. Bentuk paking tidak boleh menyulitkan calon konsumen dalam pemakaiannya, seperti memudahkan dibuka, memudahkan dibawa, memudahkan diambil, dan memudahkan dituang.

6. Faktor keindahan. paking harus menggunakan gambar yang bisa menambah selera konsumen dengan melihatkan kelezatan dan kesegaran barang melalui penampilan bentuk,logo dan warna.

Tabel 1. Profil Responden

\begin{tabular}{lll}
\hline No & \multicolumn{1}{c}{ Komponen } & Pedagang \\
& & \\
\hline 1. & Usia 31-40 Tahun & 3 Orang \\
\hline 2. & Jenis Kelamin Perempuan & 15 Orang \\
\hline 3. & Jenjang Pendidikan Tidak Sekolah & 2 Orang \\
\hline
\end{tabular}

Profil responden dapat ditunjukkan pada Tabel 1. Dimana hal tersebut menunjukan usia, jenis kelamin dan jenjang pendidik bagi responden. Kegiatan penyuluhan yang dilakukan warga Losari Lor, Kecamatan Losari, Kabupaten Brebes berupa pemaparan materi, pelatihan cara pembuatan nugget telor asin dan tanya jawab dengan ibu-ibu kader desa Losari Lor. Berdasarkan hasil kegiatan dan di evaluasi, maka didapat pencapaian target yang terlihat di Tabel 2.

Tabel 2. Hasil Evaluasi Kegiatan

\begin{tabular}{lrrl} 
& Target & & \multicolumn{1}{c}{ Pencapaian } \\
\hline $\begin{array}{l}\text { Ibu-ibu kader } \\
\text { pengemasan/paking }\end{array}$ & memahami & pentingnya & Peserta memahami materi yang sudah \\
meningkatkan & untuk & disampaikan oleh pemateri mengenai \\
jual produk & & daya & $\begin{array}{l}\text { kemasan } \\
\text { yang baik }\end{array}$ \\
\hline
\end{tabular}




\begin{tabular}{|c|c|c|}
\hline & Target & Pencapaian \\
\hline $\begin{array}{l}\text { Ibu-ibu } \\
\text { alternatif } \\
\text { produk mereka }\end{array}$ & $\begin{array}{l}\text { kader } \\
\text { pengemasan }\end{array}$ & $\begin{array}{l}\text { Ibu-ibu kader mengganti kemasan } \\
\text { dengan memberikan label pada } \\
\text { kemasan }\end{array}$ \\
\hline \multicolumn{2}{|c|}{$\begin{array}{l}\text { Peningkatan } \\
\text { pendapatan atau peningkatan jumlah penjualan }\end{array}$} & $\begin{array}{l}\text { Pendapatan } \\
\text { meningkat dalam satu bulan dari } \\
\text { keseluruhan pelaku usaha ibu-ibu } \\
\text { kader }\end{array}$ \\
\hline
\end{tabular}

Pelabelan yang baik pada kemasan barang akan mempengaruhi minatbeli konsumen, tetapi tetap ada faktor lain yang bisa mempengaruhi (Saeed et al. 2013).

\section{SIMPULAN}

Pengabdian pada wargat yang dilakukan ini bersama mahasiswa peserta KKN tahun 2020 ialah salah satu program Universitas Muhadi Setiabudi pelaku usaha yang ada di Desa Losari Lor, tempat kegiatan KKN UMUS, hal ini merupakan sebagai bagian kepedulian UMUS terhadap lingkungan, pembangunan kesejahteraan ekonomi warga di sekitarnya, hasil kegiatan ini terlihat redahnya pemahaman peserta dalam membuat label dan kemasan ,salah satunya ialah masih terdapat beberapa kemasan yang kurang bagus dan tidak melindungi produknya, sehingga membuat produk itu rusak, dan pelabelan masih kurangnya bagus, baik bentuk, diskripsi, tidak mencantumkan legalitas seperti PiRt dan halal yang biasa disebut pada kemasan pada umumnya. Label PIRT, halal MUI dan BPOM untuk produk pangan, terdapat potensi besar bagi pelaku usaha warga Losari Lor mengembangkan usahanya dengan menningkatkan kemasan dan labelnya agar lebih menarik dan disukai konsumen, sehingga bisa bersaing dengan produsen yang sejenis lainnya.

\section{DAFTAR PUSTAKA}

Angipora, Marinus. (2002). Dasar-Dasar Pemasaran. Jakarta: PT. Raja Grafindo Persada.

Basu Swastha. (1999). Manajemen Pemasaran Modern. Edisi Ketiga Yogyakarta: Liberty.

Cenadi, Christine Suharto. Peranan Desain Kemasan dalam Dunia Pemasaran. Jurnal Nirmala, Vol 2 No 1, Januari 2000, 92-103.

Kotler, Philip dan Kevin Lane Keller. (2003). Manajemen Pemasaran. Jakarta: PT. Indeks.

Kotler Marianne Rosner Klimchuk, \& Sandra. (2003). Manajemen Pemasaran. Jakarta: PT. Indeks.

A. Krasovec. (2007). Desain Kemasan. Jakarta: Erlangga.

Natadjaja, L. (2002). Pengaruh Komunikasi Visual antar Budaya Terhadap Pemasaran Produk pada Pasar Ekspor ditinjau dari warna dan Ilustrasi Desain Kemasan. Jurnal Nirmana. Vol 4 No 2 Hal 158-168.

Saeed, R., R.N. Lodhi, A. Rauf, M.I. Rana, Z. Mahmood, \& N. Ahmed. (2013). Impact of labeling on customer buying behavior in Sahiwal Pakistan. World applied sciences journal, vol. 24(9): 1250-1254. 